\title{
Pode-se falar em gêneros na televisão?
}

NAS ÚlTIMAS DÉCADAS, a idéia de gênero tem sofrido um questionamento esmagador, de parte inicialmente da crítica estruturalista e posteriormente do pensamento dito pósmoderno, para os quais esse tipo de discussão se tornou alguma coisa anacrônica, quando não irrelevante. Maurice Blanchot (1959), por exemplo, defendia, em seu tempo, que as únicas coisas realmente importantes são as obras na sua individualidade, independentemente de como as possamos classificar ("tudo se passa como se os gêneros tivessem desaparecido e só a literatura fosse afirmada..."). No mesmo contexto, Roland Barthes (1988) defendia o texto em si como uma força subversiva capaz de dissolver todas as espécies de classificação ("Como classificar Georges Bataille?... É tão desconfortável responder a essa pergunta que, em geral, se prefere esquecer Bataille nos manuais de literatura."). De forma um pouco mais flexível, Jacques Derrida (1980) problematizava a identificação de uma obra literária com um gênero, considerando que, ao penetrar no interior de um gênero, a obra o transformava em outra coisa. Para complicar, sabemos que as obras realmente fundantes produzidas em nosso século não se encaixam facilmente nas rubricas velhas e canônicas e quanto mais avançamos na direção do futuro, mais o hibridismo se mostra como a própria condição estrutural dos produtos culturais.

No entanto, por mais que Blanchot, Barthes e Derrida queiram destronar as categoriais, eles não deixam de operar dentro de uma categoria, que é a literatura. E se lhes parece possível dizer que não existem mais romances, nem poemas, nem tragédias ou comédias, resta todavia uma categoria que os abrange todos, o livro, pólo de permanência e de resistência de uma cultura, quiçá de uma civilização, de uma Weltan-schauung que se recusa a integrar-se Professor da PUCSP passivamente no terreno de outros meios de expressão, como o disco, o cinema, a 
televisão, tudo isso que parece exprimir uma outra cultura, uma outra economia e uma outra visão de mundo. Para Marjorie Perloff, o livro pode ser tomado ele próprio como um gênero (recordemo-nos do projeto do Livre de Mallarmé, tentativa de ampliação ao extremo das possibilidades últimas desse meio). Enquanto gênero, o livro "se contraporia a todos esses meios não livrescos (e cada vez mais não impressos), que estão prestes inclusive a ocupar o seu espaço como o lugar da literatura" (Perloff, 1995: 4).

Poderíamos perguntar então: acabaram-se realmente os gêneros (e, por extensão, todas as classificações que nos permitiam vislumbrar um pouco de ordem na selva da cultura) ou os nossos conceitos de gênero já não são mais suficientes para dar conta da complexidade dos fenômenos que agora enfrentamos? Talvez fosse o caso de recorrer a um conceito mais flexível ou melhor adaptável a um mundo em expansão e em rápida mutação. De todas as teorias do gênero em circulação, a de Mikhail Bakhtin nos parece a mais aberta e a mais adequada às obras de nosso tempo, mesmo que também Bakhtin nunca tenha dirigido a sua análise para o audiovisual contemporâneo, ficando restrito, como os demais, ao exame dos fenômenos lingüísticos e literários em suas formas impressas ou orais. Para o pensador russo, gênero é uma força agluti-nadora e estabilizadora dentro de uma determinada linguagem, um certo modo de organizar idéias, meios e recursos expressivos, suficientemente estratificado numa cultura, de modo a garantir a comunica-bilidade dos produtos e a continuidade dessa forma junto às comunidades futuras. Num certo sentido, é o gênero que orienta todo o uso da linguagem no âmbito de um determinado meio, pois é nele que se manifestam as tendências expressivas mais estáveis e mais organizadas da evolução de um meio, acumuladas ao longo de várias gerações de enunciadores. Mas não se deve extrair daí a conclusão de que o gênero é necessariamente conservador. Por estarem inseridas na dinâmica de uma cultura, as tendências que preferencialmente se manifestam num gênero não se conservam ad infinitum, mas estão em contínua transformação no mesmo instante em que buscam garantir uma certa estabilização. "O gênero sempre é e não é o mesmo, sempre é novo e velho ao mesmo tempo. O gênero renasce e se renova em cada nova etapa do desenvolvimento da literatura e em cada obra individual de um dado gênero. Nisto consiste a sua vida" (Bakhtin, 1981: 91).

A palavra gênero deriva do latim genus/ generis (família, espécie) e não se vincula etimologicamente, malgrado a aparente homofonia, com as palavras gene e genética (do grego génesis: geração, criação). Apesar disso, há uma inequívoca relação entre o que faz o gênero no meio semiótico (ou seja, no interior de uma linguagem) e o que faz o gene no meio biológico. Os geneticistas definem o gene como uma entidade replicante, presente nas moléculas de DNA, cuja função principal é transmitir às novas células que estão sendo formadas as informações básicas que vão garantir a preservação de uma determinada espécie. O paradoxal com relação aos genes é que, embora eles sejam entidades conservadoras por missão biológica, eles são também os responsáveis pela evolução da vida desde as formas mais simples às mais complexas, através de um longo processo de seleção natural. Como se sabe, o zoólogo e geneticista Richard Dawkins, em seu livro The Selfish Gene, defendeu a idéia de que os genes não são os únicos responsáveis pela evolução: quando a questão é a cultura humana, temos de pensar num equivalente "cultural" do gene - segundo ele, o meme - que se encarregaria da mesma função replicante das entidades genéticas. A palavra meme foi criada a partir de uma corruptela da palavra grega mímesis (imitação) e se justifica pelo fato de, segundo Dawkins (1979: 211-222), a imitação ser a forma básica de replicação dos memes. $\mathrm{O}$ problema da argumentação de Dawkins é a imprecisão ou falta de critérios na caracterização dos memes (“Exemplos de memes são 
melodias, idéias, slogans, modas do vestuário, maneiras de fazer potes ou de construir arcos."), sobretudo porque sabemos que, no terreno da cultura, o que se "imita" ou se assimila não são os enunciados diretamente (uma melodia, uma idéia, um slogan), mas estruturas abstratas, arranjos sintáticos, modos de selecionar e combinar. $\mathrm{Na}$ minha opinião, os gêneros discursivos, tais como Bakhtin os imaginou, se estendidos para toda a produção semiótica do homem, dariam muito maior precisão e coerência à idéia - de qualquer maneira fertilíssima - do replicante cultural, o meme.

Mas vamos ao tema que nos interessa. A televisão abrange um conjunto bastante amplo de eventos audiovisuais que têm em comum apenas o fato da imagem e do som serem constituídos eletronicamente e transmitidos de um local (emissor) a outro (receptor) também por via eletrônica. Cada um desses eventos singulares, cada programa, cada capítulo de programa, cada bloco de um capítulo de programa, cada entrada de reportagem ao vivo, cada vinheta, cada spot publicitário, constituem aquilo que os semioticistas chamam de um enunciado. Os enunciados televisuais são apresentados aos espectadores numa variabilidade praticamente infinita. A rigor, poder-se-ia dizer que cada enunciado concreto é uma singularidade que se apresenta de forma única, mas foi produzido dentro de uma certa esfera de intencionalidades, sob a égide de uma certa economia, com vistas a abarcar um certo campo de acontecimentos, atingir um certo segmento de telespectadores e assim por diante. Dessa maneira, malgrado único em sua ocorrência singular, ele ilustra ou espelha uma determinada possibilidade de utilização dos recursos expressivos da televisão, um certo conceito de televisão, e isso se expressa não apenas nos seus conteúdos verbais, figurativos, narrativos e temáticos, como também no modo de manejar os elementos dos códigos televisuais. Existem algumas modalidades relativamente estáveis de organizar esses elementos, ou dito de outra maneira, existem esferas de intenção mais ou menos bem definidas, no interior das quais os enunciados podem ser codificados e decodificados de forma relativamente estável por uma comunidade de produtores e espectadores até certo ponto definida. Esses campos de acontecimentos audiovisuais são herdados da tradição, mas não apenas da tradição televisual (muitos derivam da literatura, outros do cinema, ou do teatro popular, do jornalismo e assim por diante), nem tampouco esses "replicantes" são assimilados tais e quais, havendo sempre um processo inevitável de metamorfose que os faz evoluir na direção de novas e distintas possiblidades.

Para Mikhail Bakhtin, essas esferas de acontecimentos - ou diríamos nós mais tecnicamente: esses modos de trabalhar a matéria televisual - podem ser chamados de gêneros. Eles existem em grande quantidade, chegam a ser mesmo inumeráveis, aparecem e desaparecem ao sabor dos tempos, alguns deles predominam mais num período do que em outro, ou mais numa região geográfica do que em outra, muitos deles subdividem-se em outros gêneros menores. Os gêneros existem numa diversidade tão grande que muitas vezes se torna complicado estudá-los enquanto categorias. De fato, como colocar no mesmo pé de igualdade eventos audiovisuais tão distintos entre si, como uma narrativa de ficção seriada, a transmissão ao vivo de uma partida esportiva, o pronunciamento oficial de um presidente, um videoclipe, um debate político, uma aula de culinária, uma vinheta com motivos abstratos, uma missa ou um documentário sobre o fundo do mar? Os gêneros são categorias fundamentalmente mutáveis e heterogêneas (não apenas no sentido de que são diferentes entre si, mas também no sentido de que cada enunciado por estar "replicando" muitos gêneros ao mesmo tempo). "A riqueza e a diversidade dos gêneros discursivos são ilimitadas, porque as possibilidades de atividade humana são também inesgotáveis e porque cada esfera de atividade contém um repertório inteiro de gêneros discursivos que se diferenciam e 
se ampliam na mesma proporção que cada esfera particular se desenvolve e se torna cada vez mais complexa" (Bakhtin, 1986: p. 60). Não compreender essa vertiginosa variedade pode implicar numa concepção de gênero esclerosada, esta sim desprovida de sentido, anacrônica e irrelevante numa civilização como a nossa.

Como não é possível tratar de todos os gêneros televisuais, visto que nem sabemos quantos e quais são em sua totalidade, vamos a seguir tratar de dois deles, aqueles que nos pareceram exemplares e melhores testemunhas da diversidade esfuziante dos gêneros. São eles: as formas fundadas no diálogo e as narrativas seriadas. Outros gêneros, como o telejornal, as transmissões ao vivo, o videoclipe e outras formas musicais serão abordados posteriormente, em artigos futuros. Na verdade, este é um trabalho em progresso, que deverá render desdobramentos posteriores. A idéia aqui é apenas fazer uma pequena demonstração da variabilidade infinita da televisão, do amplo leque de possibilidades que ela oferece aos realizadores e das diferentes modalidades de recepção que ela demanda, com seus distintos graus de participação, credibilidade, legibilidade e suspensão de descrença.

\section{Formas Fundadas no Diálog॰}

Fala-se muito em "civilização das imagens" a propósito da hegemonia da televisão a partir da segunda metade deste século, mas a televisão, paradoxalmente, é um meio bem pouco "visual" e o uso que ela faz das imagens é, salvo as exceções de honra, pouco sofisticada. Herdeira direta do rádio, ela se funda primordialmente no discurso oral e faz da palavra a sua matéria-prima. Isso mudou um pouco nos últimos anos. Agora há uma maior utilização de recursos gráficos computadorizados nas vinhetas de apresentação, mas, no essencial, a televisão continua oral, como nos pri-mórdios de sua história, e a parte mais expressiva de sua programação segue dependendo basica- mente de uma maior ou menor eloqüência no manejo da palavra oralizada, seja da parte de um apresentador, de um debatedor, de um entrevistado, ou de qualquer outro. Não conheço nenhuma estatística a este respeito, mas a simples recepção cotidiana da televisão já demonstra (e se alguém duvida, basta, a qualquer momento, "zapar" todos os canais de televisão) que a maioria esmagadora dos programas se funda na imagem prototípica de uma talking head (cabeça falante) que serve de suporte para a fala de algum protagonista. Talvez isso se explique por imperativos técnicos e econômicos: o depoimento oral, a entrevista, o debate, o discurso do âncora constituem as formas mais baratas de televisão e aquelas que oferecem menos problemas para a transmissão direta ou para o ritmo veloz de produção. Quando é preciso construir uma imagem com atores, figurantes, locação, cenários, figurinos, maquia-gem, texto dramatúrgico, montagem e efeitos gráficos ou visuais de toda espécie, os custos crescem em progressão geométrica e o tempo de produção se torna infinitamente mais lento.

Essa disponibilidade para o discurso oral, de um lado, desviou a televisão para a facilidade, a comodidade e a banalidade dos talk shows, em geral voltados para a celebração de suas próprias estrelas, ou para algumas de suas derivações ainda mais degeneradas, como os programas de auditório e os reality shows (programas de intrigas domésticas e agressões físicas ou verbais, em geral protagonizados por um lumpesinato em estado terminal, que aceita a humilhação pública por quaisquer trocados). Mas, de outro lado, favoreceu também o ressurgimento na televisão de formas discursivas muito antigas e muito vitais, formas que estão na raiz mais profunda de toda a nossa cultura: aquelas que se fundam no diálogo. Dizemos "formas" em geral e no plural, porque, na televisão, o diálogo pode assumir as mais variadas modalidades: a entrevista, o debate, a mesa redonda e até mesmo o monólogo que pressupõe algum tipo de interlocução com um diretor oculto ou 
com o telespectador. Naturalmente, a maior ou menor eloqüência desse gênero televisual depende muito da grandeza maior ou menor das pessoas que temos na tela como debatedores, sejam eles os representantes do programa ou da televisão (apresentadores, âncoras, entrevistadores), sejam eles os representantes da sociedade, os entrevistados ou protagonistas.

Bakhtin (1981: 94-96) localiza o surgimento do diálogo como gênero na Grécia antiga, a partir principalmente do método socrático, que serviu de modelo a praticamente todos os grande dialogistas do primeiro período (Xenofonte, Ésquilo, Fédon, Alexameno, Glaucon, Craton, Simmios, Euclide, Anthisteno etc.). Sócrates colocava as pessoas umas diante das outras e as fustigava ao debate. Atento sobretudo às oposições e contradições, ele conduzia os debatedores a encarar as questões sobre todos os ângulos, mas sem jamais propor um caminho ou induzir uma conclusão final. Naturalmente, como apenas conhecemos toda essa fortuna filosófica através do filtro de Platão, o método socrático nos parece hoje apenas um recurso pedagógico do "mestre" para conduzir os seus discípulos a uma verdade já descoberta, acabada e indiscutível, como de resto acabou acontecendo com o diálogo filosófico nos períodos posteriores a Sócrates, reduzido que foi a uma mera técnica de exposição de conceitos dogmáticos de mundo. Mas para Sócrates, o diálogo não era apenas uma "forma", no sentido puramente técnico do termo: ele é o próprio alicerce de toda uma cosmovisão filosófica que acredita na natureza dialógica (plurívoca, contraditória) da verdade.

"O gênero se baseia na concepção socrática da natureza dialógica da verdade e do pensamento humano sobre ela. $\mathrm{O}$ método dialógico de busca da verdade se opõe ao monologismo oficial que se pretende dono de uma verdade acabada, opondo-se igualmente à ingênua pretensão daqueles que pensam saber alguma coisa. A verdade não nasce, nem se encontra na cabeça de um único homem; ela nasce entre os homens, que juntos a procuram no processo de sua comunicação dialógica." (Bakhtin, 1981: 94).

O diálogo socrático utilizava vários procedimentos, dos quais os mais importantes eram a síncrise e a anácrise. Entendiase por síncrise a confrontação de dois ou mais pontos de vista sobre um mesmo assunto. Era muito importante, portanto, que um debate tivesse debatedores com pontos de vista diferentes, uma vez que não há diálogo possível quando todos pensam exatamente da mesma maneira. Anácrise, por sua vez, era o nome que se dava aos métodos de provocar a palavra do interlocutor, forçando-o a colocar-se e externar claramente a sua opinião. Segundo Bakhtin, Sócrates, como bom debatedor, foi um astuto manejador da anácrise. Ele tinha uma habilidade incomum para fazer as pessoas se expressarem, mesmo quando as idéias não estavam ainda bem formuladas: a clareza vinha do diálogo e da consideração das ponderações do(s) outro(s). Assim, os protagonistas dos diálogos socráticos eram homens de idéias ("ideólogos", na terminologia de Bakhtin), mesmo quando se tratavam de pessoas simples, incorporadas ao diálogo como debatedores involuntários. No espaço da ágora, eles encenavam aquele que talvez seja o drama maior da humanidade: "a procura e a experimentação da verdade" (Bakhtin).

Talvez possa parecer um exagero dizer que temos diálogos socráticos hoje na televisão. De fato, os debates que se vê e se ouve nos talk shows convencionais estão longe de configurarem uma maiêutica da procura da verdade. Mas não estamos tratando aqui de banalidades. $\mathrm{O}$ retorno à oralidade - ou, mais exatamente, o advento de uma segunda fase da oralidade, mediada por tecnologias de gravação e transmissão (cfme. Walter Ong, 1987: 133-136) - proporcionado pelo rádio e pela televisão, abriu um espaço novo para o ressurgimento do diálogo em condições muito próximas do modelo socrático. Mas essa possibilidade teórica só rendeu resultados reais em algumas propostas mais ousadas de programas, em geral praticadas por televisões que fogem 
do esquema das grandes redes nacionais ou internacionais. Os mais belos exemplos são, certamente, as séries televisuais realizadas por Jean-Luc Godard e Anne-Marie Miéville, entre 1976 e 1978, para o Institut National de l'Audiovisuel (França). Numa entrevista concedida a Colin MacCabe (1980: 160), Godard refere-se nominalmente ao método socrático como modelo inspira-dor dessas séries. Numa outra entrevista, concedida a Claude-Jean Philippe (compilada em Godard, 1985: 412), o cineasta lamenta que o pensamento ocidental, a partir de Platão, tenha estado historicamente vinculado à cultura escrita, à cultura do livro, perdendo os seus vínculos com o diálogo socrático, de natureza fundamentalmente oral: no dizer de Godard, Platão transformou o método socrático num best seller!

A primeira dessas séries - Six Fois Deux (1976; também conhecida como Sur et Sous la Communication) - mostra um Godard ainda fortemente influenciado pelo pensamento marxista. A série consiste, como diz o título, em seis emissões com duas partes distintas cada uma, voltadas todas elas para a discussão do problema da comunicação na vida cotidiana e na mídia. A primeira parte de cada episódio é um ensaio audiovisual sobre algum aspecto da produção e consumo de mensagens no trabalho e no lazer, enquanto a segunda é um perfeito diálogo socrático entre Godard e um entrevistado sobre o assunto da matéria precedente. Os entrevistados dos seis episódios são: um camponês (Louison), um operário que é também cineasta amador nas horas vagas (Marcel), um matemático célebre (René Thom), um casal com problemas de comunicação (Jacqueline e Ludovic), um grupo de mulheres (referido na série como Nanas, gíria francesa para designar o sexo feminino) e o próprio Godard, que sai de trás das câmeras, num dos episódios, e passa a ser ele próprio entrevistado por dois jornalistas do Libération. $\mathrm{Na}$ verdade, também a corealizadora Anne-Marie Miéville aparece no final do episódio Nanas, questionando Godard e seu intento de falar em nome das mulheres.

Já no primeiro episódio, denominado Y a Personne (literalmente: "Não Há Ninguém Ali"), Godard usa uma estratégia absolutamente imprevisível para desencadear um debate. Faz anunciar nos jornais que a sua microempresa (Sonimage) está entrevistando candidatos para um emprego e, logo em seguida, dezenas de desempregados batem à sua porta. Godard os entrevista um a um, mas em lugar de fazê-los relatar suas aptidões profissionais, questiona-os sobre o problema do trabalho assalariado e sobre a venda de mão-de-obra no mercado, forçando pessoas comuns a refletir sobre complexos problemas econômicos e políticos, dos quais provavelmente eles jamais tinham se dado conta. O "emprego" que Godard oferece a essas pessoas e pelo qual oferece também um pagamento é, portanto, deixar-se entrevistar para discutir a sua própria crise de desemprego. À medida que evoluem as várias entrevistas, a questão do emprego vai desaparecendo e a reflexão sobre o modo como se organiza a sociedade passa a predominar. No final do episódio, Godard consegue arrancar de uma das candidatas uma performance exemplar do hino da Internacional Comunista! Temos então o terreno preparado para a entrada, na segunda parte, de Louison, um camponês rude mas esperto, tão eloqüente no manejo da fala que acaba driblando Godard na discussão sobre o seu métier de produtor de laticínios (falando em off para o espectador, Godard se queixa de que o seu interlocutor fala rápido demais e não abre espaço para ele entrar). Se, em Y a Personne, a questão debatida era a do desemprego nos grandes centros urbanos, no bloco Louison o camponês inverte o problema: devido à fuga das massas campesinas para as grandes cidades, a crise atual no campo é motivada pela falta de mão-de-obra e não de emprego.

Outro episódio luminoso é o terceiro da série, dividido nos blocos Photos et Cie. ("Fotos e Companhia") e Marcel, onde são entrevistados respectivamente o fotógrafo profissional Michel Laurent, especializado 
na cobertura de conflitos internacionais, e Marcel, um cineasta amador, para quem a produção de imagens e sons é um hobby, lazer de fim de semana. O fotógrafo explica, entre outras coisas, como obteve a famosa foto da execução pública de três homens, acusados de terem colaborado com o regime paquistanês, durante a guerra da independência de Bangladesh (1971). A abundância de explicações técnicas e de dados empíricos sobre a demanda de imagens no jornalismo contrastam com a violência da foto, apresentada insistentemente ao espectador, durante cerca de dez minutos. Nesse bloco, aproveitando o gancho do depoimento de Laurent, Godard discute o circuito econômico da fotografia jornalística e os seus imperativos institucionais, a gigantesca acumulação de imagens das vítimas de toda sorte de guerras e tragédias, que fez a fortuna de profissionais e magnatas da mídia, sem que jamais os protagonistas dessas fotos tenham sido consultados sobre a conveniência de ter as suas imagens difundidas publicamente, muito menos ainda pagos pelo direito de uso de suas imagens (uma vez que não eram modelos profissionais). Já Marcel, o cineasta ingênuo que filma "paisagens bonitas" nos fins de semana, com sua modesta câmera super- 8 e o dinheiro que ele ganha trabalhando numa fábrica de relógios, parece ignorar inteiramente o contexto econômico em que as imagens e os sons são produzidos e consumidos. Cinema, para ele, é entretenimento, válvula de escape para fugir da dureza e da monotonia do trabalho. Apesar dele representar, na série, o ponto de vista inocente do público, a honestidade de seus argumentos e a apaixonada defesa de seu métier de fim de semana fazem o contraponto necessário ao discurso frio e calculista do profissional bem integrado no mercado, para quem a produção de imagens é um trabalho como qualquer outro, que se faz por encomenda e se troca por dinheiro.

Já a série France/Tour/Détour/Deux/ Enfants (1978) consiste basicamente num diálogo do jornalista Robert Linard (oculto atrás das câmeras, mas audível na trilha sonora) e duas crianças em idade de alfabetização (Camille Virolleaud e Arnaud Martin), que se revezam em cada episódio. $\mathrm{O}$ título parodia uma cartilha do século XIX, escrita por Gérard Bruno, Le Tour de France par Deux Enfants. Apesar da pouca idade dos meninos, Linard não os trata como imaturos, nem se dirige a eles como normalmente os adultos se dirigem a crianças. Pelo contrário, como um bom manejador da anácri-se, ele estabelece com os meninos uma intrincada, complexa e desconcertante discussão filosófica sobre as grandes oposições da vida e do pensamento: a palavra e a imagem, a luz e a obscuridade, o ruído e o silêncio, o amor e o trabalho, o masculino e o feminino, a criação e a cópia, o consumo e a produção. Os doze episódios são construídos numa estrutura simétrica e sincrítica (referente a síncrise), fazendo alternar os segmentos de Camille e Arnauld com títulos contrapostos, que jogam um conceito contra o outro. Assim, Obscur/Chimie (Obscuro/Química) faz par com Lumière/Physique (Luz/Física), Réalité/Logique (Realidade/ Lógica) com Rêve/Morale (Sonho/Moral), Violence/Grammaire (Violência/Gramática) com Désor-dre/Calcul (Desordem/Cálculo) e assim por diante. Os diálogos com os meninos (intitu-lados Véritê) e as cenas da rotina de suas vidas (intituladas Télévision) são acompanhados pelo irônico comentário de dois apresentadores de televisão, Albert Dray e Betty Berr (no bloco Histoire), que tentam amarrar os tópicos discutidos com um esboço de história que possa servir de fio condutor aos debates (eventualmente também fazendo críticas ao próprio programa).

Em lugar de dividir o programa em capítulos, Godard e Miéville preferem trabalhar com movimentos, como na música. Não sem razão, Godard (1985: 411) definiu a série como sendo "filosofia em forma de música de câmera". No primeiro movimento, Camille e Linard discutem as diferenças entre o dia e a noite, a luz e as trevas, a imagem (física e mental) e o seu referente, 
assim como o significado da existência. No segundo, Arnaud e Linard discutem a iluminação e seus significados na vida e na representação. No terceiro, Camille, abordada por Linard no trajeto para a escola, conversa com seu interlocutor sobre o movimento e as distâncias. A estrutura é quebrada no quarto movimento, onde não há qualquer diálogo, mas apenas o dia-a-dia dos estudos na classe de Arnaud. No movimento seguinte, vemos Arnauld manejando o mimeógrafo da escola, para copiar uma apostila de cálculo, quando aparece Linard para questioná-lo sobre a imprensa, a impressão e a conservação da experiência na memória. O sexto movimento mostra Camille no recreio escolar, dialogando com Linard sobre as relações entre a escola e o trabalho, o trabalho e o dinheiro, as razões por que a escola isola as crianças do mundo dos adultos e terminam discutindo se esse isolamento poderia ser interpretado como uma forma de aprisionamento. No sétimo movimento, Linard surpreende Camille após esta ter sido repreendida pela professora e obriga$\mathrm{da}$, por castigo, a copiar cinqüenta vezes uma mesma frase. O jornalista a questiona sobre o dever, a obediência às leis, a revolta, as diferenças entre invenção e cópia, as relações entre escola e empresa. No oitavo, Linard, Arnaud e um amiguinho da escola (que não aparece em campo) discutem a troca, o comércio, a propriedade, a multiplicação, a matemática, o dinheiro e o valor das coisas. No nono movimento, Camille está em seu quarto lendo uma história em quadrinhos e ouvindo Mozart num fone de ouvido. Surge Linard e ambos conversam sobre a música, sua origem, seu papel na relação com a imagem, o ruído, as relações entre saber e poder. No décimo movimento, Arnaud e Linard estão vendo um filme de James Bond na televisão e conversam sobre a própria televisão e sobre o espetáculo, o olhar, a digestão, o tédio e a solidão. No penúltimo movimento, novamente quebrando a estrutura, Camille janta e prepara-se para dormir, sem dizer uma palavra. Finalmente, no último movimento, Camille já está dormindo. Arnaud se prepara para assumir o seu leito, quando Linard o aborda para discutir a vigília, o sonho, o pensamento, a existência, o que é claro e o que é obscuro na vida, a felicidade e o infortúnio, a vida e a morte, as origens e o sentido das coisas.

Em 1995, Godard e Miéville foram encarregados pelo British Film Institute de conceber o episódio francês da série One Hundred Years of Cinema (Cem Anos de Cinema). O episódio se chamou Deux Fois Cinquante Ans de Cinéma Français e permitiu ao casal retomar as suas primeiras experiências com o diálogo socrático. Ele consiste basicamente num tenso debate entre Godard e o ator Michel Piccoli, encarregado pela prefeitura de Lyon (cidade onde os irmãos Lumière começaram a produzir os seus primeiros filmes) de planejar os eventos comemorativos dos cem anos de história do cinema. Nesse episódio temos, de um lado, um Piccoli ufanista, deslumbrado com a missão oficial de que foi investido e com o seu próprio projeto de mostrar ao mundo o papel da França na invenção do cinema; de outro, um Godard cético e cínico, que desmonta os sonhos imperiais de seu interlocutor, desmistifica os velhos monumentos da história e lamenta o fato dos contemporâneos terem perdido a memória dos acontecimentos. O diálogo é tenso, às vezes até descon-fortável, malgrado mantido nos limites da civilidade. Godard encurrala Piccoli e o obriga a enfrentar questões pouco cômodas sobre o suposto papel inaugural dos irmãos Lumière, sobre a decadência do cinema francês e o estado geral da arte cinematográfica em todo o mundo. Não há muito o que comemorar, parece querer dizer Godard, enquanto seu interlocutor faz das tripas coração para salvar o seu projeto. Quem ganha é o espectador, que tem a chance de presenciar um grande debate na melhor tradição socrática.

Certamente, não foi Godard quem inventou o debate filosófico na televisão. Diríamos que esse "gênero" tem uma longa, sólida e impressionante história e, algum dia, alguém terá de reconstituí-la. A televi- 
são, tantas vezes acusada de massificação e banalidade, tem sido também o lugar onde o pensamento ganhou um impulso novo, liberado que foi dos constrangimentos retóricos da sua forma escrita. Entre os melhores exemplos de debate intelectual na televisão, poderíamos citar as várias séries conduzidas por Bill Moyers, nos E.U.A., desde os anos 70, tais como World of Ideas, Healing and the Mind e The Power of the Word, passando por alguns dos debates mais luminosos da televisão, como os que Moyers travou com o antropólogo Joseph Campbell - The Power of Myth (1988) - e com o poeta Robert Bly - A Gathering of Men (1989). Em geral, Moyers evita ambientar seus diálogos em estúdios de televisão, preferindo antes colocar seus debatedores em cenários naturais - jardins, bosques, casas de campo, sofás ao pé de lareiras - e conduzir as discussões num clima de conversa informal. $\mathrm{O}$ equivalente francês de Moyers poderia ser Bernard Pivot, o apresentador de Apostrophes, mas há também a proposta alternativa de Océaniques, dirigido por Pierre-André Boutang, que consiste em colocar face a face dois debatedores de peso (o próprio Godard debateu, em dezembro de 1987, com a escritora e cineasta Marguerite Duras). Na América Latina, tivemos três exemplos bastante maduros de programas dedicados ao debate intelectual, eventualmente também filosófico. O primeiro foi Teleanálisis (Chile, 1984/89), dirigido por Augusto Gongorra, ainda nos duros anos da ditadura militar. O segundo foi Incidentes (Argentina, 1996), dirigido por Jorge la Ferla e dedicado à discussão de temas relacionados com a contemporaneidade. O debate sobre o papel dos intelectuais, travado por Beatriz Sarlo, editora da revista Punto de Vista, e Jorge Lanata, jornalista do periódico Página/12, foi de longe o melhor, particularmente porque os dois antagonistas tinham opiniões contrárias sobre os vários tópicos discutidos e isso tornava mais sincrítico o enfren-tamento das idéias. O terceiro exemplo é a série brasileira Diálogos Impertinentes (desde 1995), dirigida por Gabriel Prioli, onde se colocam em confronto duas personalidades proeminentes em suas respectivas áreas de atuação para discutir um tema geralmente de caráter abstrato e transdisciplinar (como a dor, o desejo, o acaso, a utopia, o belo, o obsceno, a razão, o feminino, a liberdade, a morte etc.). No Brasil, há ainda o notável exemplo da série Ética (1994), dirigida por Paulo Morelli e Dario Vizeu, que se não chega a ser exatamente um programa dialógico no sentido socrático-bakhtiniano, uma vez que está estruturado a partir de depoimentos em forma de monólogos de importantes filósofos e intelectuais brasileiros, apresenta entretanto uma eloqüente pesquisa iconográfica, sob a forma de imagens que perpassam a tela em nítido contraponto com o que é dito na trilha sonora.

A grandeza dos resultados obtidos em todos esses programas deriva, naturalmente e em primeiro lugar, das inteligências neles envolvidas, mas também de algumas soluções estruturais, que seria interessante comentar, já que estamos tratando aqui do diálogo como "gênero". Antes de mais nada, a eficácia do diálogo na televisão depende de uma autonomia real que se concede aos participantes. Não pode haver debate onde há o constrangimento de um script determinando o que se deve dizer, de que maneira dizê-lo, ou em que circunstância intervir. $\mathrm{O}$ debate deve ser fruto exclusivo da fogueira das idéias e a astúcia única que se espera de um bom moderador é sua técnica de fustigar as idéias, para que elas possam emergir. Crucial nessas circunstâncias é a liberação dos constrangimentos de tempo. As televisões comerciais, no geral, operam sob severa economia temporal, em razão dos interesses econômicos e do esquadrinhamento dos anunciantes ao longo da programação. Grande parte dos debates promovidos sob essas circunstâncias são marcados pelo ritmo ferrenho do cronômetro, com perguntas e respostas desferidas à queima-roupa, sem intervalos para pausas, hesitações ou reflexões. A possibilidade de um real diálogo filosófico, nem é preciso dizer, depende muito da conquista de um outro timing tele- 
visual, mais livre e mais fluido do que aquele imposto à televisão pela metralhadora de cortes dos spots publicitários. Nas séries de Godard e Miéville, por exemplo, não há fala plena o tempo todo: os depoimentos são largamente interrompidos por suspensões, silêncios e pausas para reflexão. A linguagem dos protagonistas é, como em toda genuina comunicação oral, errante, flutuante, incerta, construída por tentativas e erros, configurando uma espécie de "gagueira fundamental", expressão cunhada por Philippe Dubois (1992: 169), a propósito justamente das séries televisuais de Godard e Miéville, e a partir de uma idéia de Deleuze. Os longuíssimos intervalos de silêncio de Ludovic, na primeira série de Godard e Miéville, inteiramente respeitados na edição, são os exemplos mais eloqüentes dessa busca de um timing próprio para uma televisão reflexiva. Resultados semelhantes podem ser verificados no magnífico debate entre Bernard Pivot e Marguerite Duras para o programa francês Apostrophe (levado ao ar a 28 de setembro de 1984 pela Antenne 2, sob direção de Jean-Luc Léridon): enquanto Pivot, histriônico e bem formado na tradição televisual, bombardeia de perguntas a escritora e tenta acelerar o ritmo das falas, Duras prefere manter o debate num ritmo introspectivo, meditativo, falando em voz baixa, quase sussurrada, com longas pausas para reflexão, muito silêncio entre as frases e uma linguagem plena de hesitações. Mais radical ainda, o episódio El Cementerio da série espanhola Qué Sabe Nadie (1990), dirigida por Téo Escamilla para a rede Telemadrid, mostra um diálogo extremamente tenso e difícil, gravado no interior de uma penitenciária, entre o produtor Jesus Quintero e um prisioneiro condenado por homicídio. As falas hesitantes dos dois antagonistas, cheias de suspensões e angustiantes intervalos de silêncio, parecem dizer mais pelo que omitem do que por aquilo que efetivamente informam, como se fosse possível construir um diálogo não apenas com a voz, mas também com os gestos, as alterações fisionômicas, o tremor dos lábios, captados em impressionantes pri-meiríssimos planos.

\section{A Narrativa Seriada}

Como se sabe, a programação televisual é muito freqüentemente concebida em forma de blocos, cuja duração varia de acordo com cada modelo de televisão. Em geral, televisões comerciais têm blocos de menor duração que as televisões públicas, pela razão óbvia de que precisam vender mais intervalos comerciais. Uma emissão diária de um determinado programa é normalmente constituída por um conjunto de blocos, mas ela própria também é um segmento de uma totalidade maior - o programa como um todo - que se espalha ao longo de meses, anos, em alguns casos até décadas, sob a forma de edições diárias, semanais ou mensais. Chamamos de serialidade essa apresentação descontínua e fragmentada do sintagma televisual. No caso específico das formas narrativas, o enredo é geralmente estru-turado sob a forma de capítulos ou episódios, cada um deles apresentado em dia ou horário diferente e subdividido, por sua vez, em blocos menores, separados uns dos outros por breaks para a entrada dos comerciais. Muito freqüentemente, esses blocos incluem, no início, uma pequena contextualização do que estava acontecendo antes (para refrescar a memória ou informar o espectador que não viu o bloco anterior) e, no final, um gancho de tensão, que visa manter o interesse do espectador até o retorno da série depois do break ou no dia seguinte. Os episódios da série de David Lynch Twin Peaks (1990-1991), por exemplo, começavam sempre com uma rápida retrospectiva dos episódios anteriores e terminavam invariavelmente no momento mais inquietante.

Existem basicamente três tipos principais de narrativas seriadas na televisão. No primeiro caso, temos uma única narrativa (ou várias narrativas entrelaçadas e paralelas) que se sucede mais ou menos linearmente ao longo de todos os capítulos. É o caso dos teledramas, telenovelas e de alguns 
tipos de séries ou minisséries. No segundo caso, cada emissão é uma história completa e autônoma, com começo, meio e fim, e o que se repete no episódio seguinte são apenas os mesmos personagens principais e uma mesma situação narrativa. Neste caso, temos um protótipo básico que se multiplica em variantes diversas ao longo da duração do programa. É o caso basicamente dos seriados - por exemplo, o célebre Malu Mulher (1979-1981) - e de programas humorísticos do tipo Monty Python's Flying Circus (1969/74). Nessa modalidade, um episódio, via de regra, não se recorda dos anteriores, nem interfere nos posteriores: o personagem principal aparece ferido no final de um episódio, o vilão é colocado na cadeia, mas no episódio seguinte já não há mais sinal do ferimento, nem o vilão está mais na prisão. O caso mais absurdo é o desenho dirigido por Trey Park South Park (desde 1998), que tem um personagem, o Kenny, que morre em todos os episódios, mas sempre retorna vivo nos episódios seguintes. Nesse tipo de estrutura, ao contrário da modalidade anterior, não há ordem de apresentação dos episódios: pode-se invertê-los ou embaralhá-los aleatoriamente, sem que a situação narrativa se modifique. Finalmente, temos um terceiro tipo de serialização, em que a única coisa que se preserva nos vários episódios é o espírito geral das histórias, ou a temática, mas cada episódio é não apenas uma história completa e diferente das outras, como também são diferentes os personagens, os atores, os cenários e, às vezes, até os roteristas e diretores. É o caso de todas aquelas séries em que os episódios têm em comum apenas o título genérico e o estilo das histórias, mas cada segmento é uma narrativa independente. A série The Outer Limits (1964-1965, primeira versão), por exemplo, é constituída de episódios em que a única coisa em comum é a presença em cena de monstros do espaço extraterreste, sejam eles insetos gigantes, microorganismos parasitários ou rochas inteligentes. $\mathrm{Na}$ mesma categoria se poderia enquadrar também a série brasileira Comédia da Vida
Privada (1995-1997), em que as diferentes histórias mensais têm em comum apenas o fato de focalizarem sempre a vida doméstica e o eterno conflito homem-mulher (além, naturalmente, dos arrojados estilos de miseen-scène e edição). Seguindo principalmente sugestões de Renata Pallottini (1998: 31, 40), adotaremos, sempre que pertinente, a seguinte terminologia: vamos chamar de $\mathrm{ca}$ pítulos os segmentos do primeiro tipo de serialização, de episódios seriados os segmentos do segundo tipo e de episódios unitários as narrativas independentes do terceiro tipo.

Naturalmente, os três tipos de narrativas podem às vezes se confundir. As telenovelas brasileiras pertencem, sem dúvida, à primeira modalidade, ou seja, a(s) histó-ria(s) iniciada(s) no primeiro capítulo continua(m) ao longo de toda a série, até o desfecho final no último capítulo, mas pode $(\mathrm{m})$ arrastar-se indefinidamente, repetindo ad infinitum as mesmas situações ou criando situações novas, enquanto houver altos índices de audiência. Por outro lado, existem seriados em que, malgrado se possa verificar uma estrutura básica de episódios independentes, permitindo, portanto, que possam ser assistidos em qualquer número ou ordem, há uma situação teleológi-ca, um início que explica as razões do(s) conflito(s) e uma espécie de objetivo final que orienta a evolução da narrativa. Aqui também a série pode desdobrar-se ao infinito, enquanto houver audiência, mas há um episódio inaugural que explica o contexto da série e é possível ainda que, em algum momento, os realizadores resolvam colocar um ponto final na história, fazendo com que os personagens principais possam atingir uma meta prefixada. A situação básica do seriado Malu Mulher, por exemplo, se explica no primeiro episódio, com o conflito conjugal, a separação do casal e o trauma da filha. Todos os demais episódios serão derivações do fato de Malu estar descasada, ter de iniciar uma nova vida sozinha e ainda trabalhar o trauma da filha. No sériado The Fugitive (1964-1967), temos uma situação básica também apresentada no primeiro episódio: 
o Dr. Richard Kimble, equivocadamente acusado de matar a sua esposa, passa seus dias interminavelmente fugindo da polícia e tentando encontrar o verdadeiro assassino, antes que ele próprio seja capturado. Cada um dos episódios seguintes será uma variação em torno da fuga e da investigação do crime. Finalmente, três anos depois do início do seriado, o crime é desvendado e o assassino fuzilado pelo mesmo policial que perseguia Kimble, finalizando portanto a narrativa.

Há várias explicações sobre as razões que levaram a televisão a adotar a serialização como a principal forma de estrutura-ção de seus produtos audiovisuais. Para muitos, a televisão, muito mais do que os meios anteriores, funciona segundo um modelo industrial e adota como estratégia produtiva as mesmas prerrogativas da produção em série que já vigoram em outras esferas industriais, sobretudo na indústria automobilística. A necessidade de alimentar com material audiovisual uma programação ininterrupta teria exigido da televisão a adoção de modelos de produção em larga escala, onde a serialização e a repetição infinita do mesmo protótipo constituem a regra. Com isso, é possível produzir um número bastante elevado de programas diferentes, utilizando sempre os mesmos atores, os mesmos cenários, o mesmo figurino e uma única situação dramática. Enquanto produtos como o livro, o filme e o disco de música são concebidos como unidades mais ou menos independentes, que demoram um tempo relativamente longo para serem produzidos, o programa de televisão é concebido como um sintagma-padrão, que repete o seu modelo básico ao longo de um certo tempo, com variações maiores ou menores. $\mathrm{O}$ fato mesmo da programação televisual como um todo constituir um fluxo inin-terrupto de material audiovisual, transmitido todas as horas do dia e todos os dias da semana, aliado ainda ao fato de que uma boa parte da programação é constituída de material ao vivo, que não pode ser editado posteriormente, exigem velocidade e racio- nalização da produção. A tradição parece demonstrar que um certo "fatiamento" da programação permite agilizar melhor a produção (o programa pode já estar sendo transmitido enquanto ainda está sendo produzido) e também responder às diferentes demandas por parte dos distintos segmentos da comunidade de telespectadores. De qualquer forma, não foi a televisão que criou a forma seriada de apresentação das mensagens. Ela já existia antes nas formas epistolares de literatura (cartas, sermões etc.), em que cada fragmento se destinava à leitura num dia diferente do ano, depois teve um imenso desenvolvimento com a técnica do folhetim, utilizada na literatura publicada em jornais desde o século passado, continuou com a tradição do radiodra-ma ou da radionovela e conheceu a sua primeira versão audiovisual com os seriados do cinema. Mas foi a televisão, sem dúvida, que deu expressão industrial e forma significante à serialização, antes praticada em outros meios de maneira apenas marginal.

Além disso, existem também razões de natureza intrínseca ao meio condi-cionando a televisão à produção seriada. Ao contrário do cinema, que exige o concurso da sala escura como condição fundan-te do ilusionismo e que, em conseqüência disso, dirige todos os olhares para um único ponto luminoso do espaço - a tela onde são projetadas as imagens -, a televisão em geral ocorre em espaços domésticos iluminados, em que o ambiente circundante concorre diretamente com o lugar simbólico da tela pequena, desviando a atenção do espectador e solicitando-o com muita freqüência. E mais: enquanto o espectador de cinema executa um ato deliberado de sair de casa, comprar um ingresso e se introduzir na sala escura com a finalidade exclusiva de assistir a um filme, o espectador de televisão é, em geral, um espectador involuntário, que se encontra "de passagem" no espaço da exibição, que em geral chega depois que o espetáculo já começou e que provavelmente já terá se retirado antes que ele se acabe, conforme o modelo do telespectador "zapando" os 
canais televi-suais com seu controle remoto, mas também o do transeunte de um aeroporto ou de uma estação de metrô, momentaneamente fisgado pela tela de um circuito fechado de televisão. Tudo isso quer dizer que a atitude do espectador em relação à mensagem televisual é não apenas eventual, como também dispersiva e distraída em grande parte das vezes.

Diante dessas contingências, a produção televisual se vê permanentemente constrangida a levar em consideração as condições de recepção e essa pressão acaba finalmente por se cristalizar em forma expressiva. Um produto adequado aos modelos correntes de difusão não pode assumir uma forma linear, progressiva, com efeitos de continuidade rigidamente amarrados como no cinema, ou então o telespectador perderá o fio da meada cada vez que a sua atenção se desviar da tela pequena. A televisão logra melhores resultados quanto mais a sua programação for do tipo recorrente, circular, reiterando idéias e sensações a cada novo plano, ou então quando ela assume a dispersão, organizando a mensagem em painéis fragmentários e híbridos, como na técnica da collage. Além disso, é preciso considerar que, na televisão, ocorre sempre uma intersecção de três tipos diferentes de "edição". Há, em primeiro lugar, a montagem interna do programa, que poderia parecer semelhante à de outros meios audiovisuais, como o cinema por exemplo. Mas há também uma outra "montagem", que se dá no nível da macroestrutura da televisão e que faz coexistir o programa stricto sensu (uma telenovela, um telejornal etc.) com os breaks e outros tipos de interrupções, além de amarrar cada capítulo ou unidade com a sua continuidade no dia seguinte. Por fim, há a "montagem" que o próprio espectador realiza, com sua unidade de controle remoto, pulando de um programa para outro, de uma emissora a outra, como um viajante errando nas ondas hertzianas. Essas três grandes estruturas de "montagem" se interpenetram e agem umas sobre as outras: a montagem interna concorre para possi- bilitar a montagem macroestrutural, uma vez que o programa pode ser interrompido a qualquer momento, e ao mesmo tempo precisa arranjar o material de tal forma a prender e interessar o espectador eventual, que está de passagem por aquele canal e que precisa de imediato entender o que está acontecendo, mesmo sem ter as informações apresentadas anteriormente.

Há que considerar também a incorporação do break à estrutura da obra. O "intervalo comercial" surgiu, muito provavelmente, por razões de natureza econômica, imposto pelas necessidades de financiamento na televisão comercial e talvez essa seja a razão porque ele é tão mal compreendido (até algum tempo atrás, os franceses o chamavam, pejorativamente, de saucis-sonage, "fatiamento" do programa como se ele fosse um salsichão). Mas a sua função estrutural não se limita apenas a um constrangimento de natureza econômica. Ele tem também um papel organizativo muito preciso, que é o de garantir, de um lado, um momento de "respiração" para absorver a dispersão e, de outro, explorar ganchos de tensão que permitem despertar o interesse da audiência, conforme o modelo do corte com suspense, explorado na técnica do folhetim. A melhor prova disso é o fato de até mesmo as televisões estatais - aquelas que não dependem de publicidade para se manter - utilizarem o recurso do break em sua programação. Segundo Balogh (1996: 152), típicos ganchos para a divisão dos blocos são os momentos de risco ou de decisão do relato, ou os momentos mais tensos no plano passional. Ela cita o caso dos momentos de suspense e tensão na conquista amorosa entre Riobaldo e Diadorim, na adaptação televisual de Grande Sertão: Veredas (1985, dirigido por Walter Avancini). Como se trata de uma aproximação difícil (um caso de homossexualidade entre jagunços), carregada de erotismo, proibição, sentimento de culpa e afastamento físico, tem-se uma situação ideal para extrair dela vários ganchos de tensão. Seccionando o relato no momento preciso em que se forma uma tensão e em que 
o espectador mais quer a continuação ou o desfecho, a programação de televisão excita a imaginação do público. Assim, o corte e o suspense emocional abrem brechas para a participação do espectador, convidando-o a prever o posterior desenvolvimento do entrecho.

Se os intervalos que fragmentam um programa de televisão fossem suprimidos e os vários capítulos diários fossem colocados em continuidade numa mesma seqüência, o interesse do programa provavelmente cairia de imediato, uma vez que ele foi concebido para ser decodificado em partes e simultaneamente com outros programas. Ninguém suportaria uma minissérie ou telenovela que fosse apresentada de uma só vez (mesmo que de forma compacta), sem interrupções e sem os nós de tensão que viabilizam o corte. Certa ocasião, pediram a Bob Wilson que apresentasse numa sala aberta ao público o seu Video 50 (série de curtíssimos sintagmas televisuais concebidos para serem inseridos aleatoriamente nos breaks de separação dos blocos de programas). $\mathrm{O}$ artista, entretanto, recusou-se a fazê-lo, alegando que seu trabalho havia sido pensado e realizado para a televisão, de forma que a sua recepção tinha de ser necessariamente bloqueada, descontínua e distraída como requer a tela pequena. Assim, não fazia sentido emendar os fragmentos e exibi-los em continuidade numa sala pública como a do cinema.

Lorenzo Vilches (1984: 57-70) define a serialização como um conjunto de seqüências sintagmáticas baseadas na alternância desigual: cada novo episódio repete um conjunto de elementos já conhecidos e que fazem parte do repertório do receptor, ao mesmo tempo em que introduz algumas variantes ou até mesmo elementos novos. $\mathrm{Na}$ produção comercial mais banal (os chamados "enlatados"), os esquemas narrativos que se repetem costumam ser estereótipos, protótipos elementares ou padrões simples e previsíveis, podendo ainda ser facilmente representados nos modelos narrativos de Propp ou de Bremond. Com o consumo rei- terado, o espectador aprende a situar com rapidez uma série dentro de uma tipologia existente (Balogh, 1990: 112). Os norteamericanos demonstram maior predileção pelos seriados de aventuras policiais, ficção científica ou pelas comédias de costumes familiares (sitcoms), os europeus preferem as minisséries de dramas históricos, os japoneses as animações (animês) derivadas dos quadrinhos (mangá) e os latino-americanos as telenovelas de tendência melodramática. Mas em condições de produção privilegiadas, é possível encontrar estruturas seriadas realmente interessantes, nas quais a repetição torna-se, como na música mini-malista, a condição inaugural de uma nova dramaturgia.

$\mathrm{Na}$ verdade, repetição não significa necessariamente redundância. Ela é, pelo contrário, princípio organizativo de vários sistemas poéticos. Peter Kivy, em seu livro The Fine Arts of Repetition (1993), vê na repetição a forma íntima mais profunda da música, comparável apenas à tecnica da repetição de padrões geométricos na arte da tapeçaria, enquanto Iuri Lotman (1978: 187-235) entendia também o verso poético como um discurso de repetições (fonológicas, rítmicas e também a repetição como recurso de produção de sentido). Discutindo a serialização nas histórias em quadrinhos, Umberto Eco (1970: 286) observa que o fluxo contínuo de variações sobre um mesmo esquema básico possibilita criar uma espécie de "poésie ininterrompue", cuja força não pode ser experimentada através do contato com apenas uma, duas ou dez histórias, "mas só depois de haver entrado a fundo nos caracteres e situações, visto que a graça, a ternura ou o riso nascem somente da repetição, infinitamente cambiante, dos esquemas, nascem da fidelidade à inspiração básica, e requerem do leitor um ato contínuo e fiel de simpatia." Omar Calabrese (1987: 44), por sua vez, rejeitando o senso comum que considera o repetitivo e o serial como o contrário do original e do artístico, vem a afirmar que a produção seriada da televisão nos permite pensar numa coisa nova, uma espécie de 
"estética da repetição", baseada na dinâmica que brota da relação entre os elementos invariantes e os variáveis.

Essa "estética da repetição" é muito bem exemplificada por Calabrese (1987: 5556) através da análise que ele faz do seriado norte-americano Bonanza (1960-1973), cujos primeiros episódios foram dirigidos por Robert Altman. Os elementos invariantes da série correspondem à iconografia básica do western, celebrizada pelo cinema: boiadeiros, aldeias, saloons, bailes na praça, manadas de gado, corridas nas pradarias, índios, country music etc. Aos poucos, variáveis vão sendo introduzidas, manchando essa platitude inicial: surge um boxeador da Inglaterra e um japonês que não consegue integrar-se ao grupo, o pistoleiro fica cego e assim por diante. No plano temático, os papéis que personificam o bem e o mal também vão sofrendo contínua redefinição ao longo do seriado. Assim, os valores clássicos do western, que parecem típicos nos primeiros episódios, vão sofrendo revisões nos episódios posteriores, até redirecionar completamente a narrativa. Além disso, temos aqui uma situação ficcional mais afinada com uma estrutura seriada do que com um padrão narrativo de tipo clássico, no sentido aristotélico do termo. A história é vaga: acompanha a saga da família Cartwright, proprietária do rancho Ponderosa, em Virginia City, Nevada, composta basicamente pelo pai Ben e os filhos Adam, Hoss e Joe, e narra os problemas que a família tem de enfrentar com bandidos e índios ou a ajuda que prestam aos outros colonos em perigo. Não há um enredo linear, uma trama a ser seguida, um objetivo final a ser perseguido (a não ser a própria autopre-servação da família), mas há um mecanismo interno de mutação que modifica o estatuto dos personagens de um episódio a outro, exigindo que o espectador reconsidere permanentemente o seu conhecimento e a sua apreciação da história. Em cada semana, alguma coisa acontece que modifica o rumo posterior dos acontecimentos e, como decorrência, esboça-se, ao longo de toda a sé- rie, uma vaga promessa de continuidade e progressão, embora cada episódio continue mantendo-se mais ou menos independente dos outros, podendo ser acompanhado sem problemas pelo espectador ocasional. No dizer de Calabrese, Bonanza consegue criar diversos desníveis narrativos e temporais: "a história acabada em cada episódio, a história aberta da série e um modelo intermediário que consiste em uma história aberta para um número definido de capítulos" ( $p$. 56).

Outros modelos de narrativa seriada que procuram extrair o máximo do jogo entre variantes e invariantes são também examinados por Calabrese. Ele cita, por exemplo, a série norte-americana Columbo (1972-1979), que tem um único personagem principal - o detetive que dá título ao seriado - e uma situação básica rígidamente estabe-lecida e infinitamente repetida: um crime quase perfeito, o ocultamento das provas, a competição de inteligências entre o criminoso e o investigador, a descoberta de um minúsculo erro do culpado e o desmas-caramento final. $O$ interesse da série está justamente em promover sutis variações em torno desse eixo temático aparentemente estático. Na verdade, cada episódio é realmente um exercício de variações diegéticas e estilísticas em torno do tema central, sempre assinado por diretores diferentes (alguns até bastante expressivos, como John Cassavetes e John Boorman), quase como se fossem encenações diferentes da mesma história.

Se o enfoque, seguindo a pista de Calabrese, diz respeito às variações em torno do idêntico, não há como deixar de citar um seriado brasileiro bastante inovador, o $A r$ mação Ilimitada (1985-1988), realizado para a Rede Globo sob a direção geral de Guel Arraes. Entre as suas várias virtudes, o seriado se distingue pela sua imensa capacidade de metamorfose (ele nunca é a mesma coisa a cada novo episódio) e pela sua voracidade em "deglutir" antropo-fagicamente todos os outros formatos televisuais, para devolvê-los em seguida sob a forma de paródia. 
Comparado com as outras séries brasileiras do mesmo período - Malu Mulher, O Bem Amado, Carga Pesada, Plantão de Polícia, Amizade Colorida etc. - o programa aparece nitidamente como um seriado atípico, pela maneira como joga com os esquemas da produção seriada. De um lado, há uma estrutura fortemente repetitiva, fundada no quarteto básico um tanto quanto estereotípico - Juba e Lula, os protótipos dos garotões esportistas ligeiramente alienados; Zelda, a jornalista protofe-minista; Bacana, o "menor abandonado" nada carente - e nas suas peripécias em torno da administração da estranha e suspeita comunidade/empresa Armação Ilimitada. Mas o tom farsesco da série demole todo e qualquer princípio de estabilidade, garantindo a variabilidade infinita das combinações iconográficas, temáticas e narrativas. Dependendo dos rumos que toma a(s) trama(s), Zelda tanto pode aparecer como uma feia e desengonçada dona de casa, uma intelectual vetusta e estrábica, uma vamp sensual e irresistível e até mesmo uma Iracema alencariana (no episódio Programa de Índio). Um dos personagens mais descon-certantes é o camaleônico "chefe" de Zelda, o editor do jornal Correio do Crepúsculo. Cada vez que ele aparece, em cada bloco ou episódio, sua personalidade muda completamente: ora ele parece rígido e autoritário como um ditador, ora dócil e submisso como um cachorrinho de estimação, ora ele parece estar apaixonado por Zelda e faz tudo por ela, outras vezes a trata cruelmente, como a mais baixa das funcionárias. Às vezes, ele também se transforma visualmente em porco, flor ou marionete, de acordo com o humor do bloco ou episódio. Além disso, o estilo narrativo da série é bastante indefinido, permitindo variar o tempo todo entre um sem-número de possibilidades estilísticas. Às vezes a narrativa é conduzida como se fosse um programa de rádio (as contínuas interrupções de Black Boy, o locutor-narrador dos primeiros episódios), outras vezes como uma chanchada ou programa de auditório, outras vezes ainda como uma paródia debochada dos seriados norte-americanos (os episódios Meu Amigo Mignum e A Dama de Couro), não raro absorvendo elementos formais da telenovela, do telejornal, do videoclipe, da ficção científica (o bebê Zeldinha, fruto da relação de Ronalda Cristina com algum ser extraterrestre) e fazendo citações explícitas dos outros programas da Rede Globo e de toda a história do audiovisual .

\section{Referências}

BAKHTIN, Mikhail (1986). Speech Genres \& Other Late Essays. Austin: University of Texas.

BAKHTIN, Mikhail (1981). Problemas da Poética de Dostoiévski. Rio de Janeiro: Forense.

BALOGH, Anna Maria (1990). "Televisão: serialidade, paraserialidade e repetição". In Face, vol. 3, no. 1, jan/jun.

BALOGH, Anna Maria (1996). Conjunções, Disjunções, Transmutações: da Literatura do Cinema e à TV. São Paulo: Annablume.

BARTHES, Roland (1988). 0 Rumor da Lingua. São Paulo: Brasiliense.

BLANCHOT, Maurice (1959). Le Livre à venir. Paris: Gallimard.

CALABRESE, Omar (1987). La Era Neobarroca. Madrid: Cátedra.

DAWKINS, Richard (1979). 0 Gene Egoísta. Belo Horizonte: Itatiaia.

DERRIDA, Jacques (1980). "The Law of Genre". In Critical Inquiry, vol. 7, no. 8.1, Autum.

DUBOIS, Philippe (1992). "Video Thinks What Cinema Creates". In Jean-Luc Godard: Son + Image, R. Bellour, M.L.Bandy, ed. New York: MOMA.

ECO, Umberto (1970). Apocalípticos e Integrados. São Paulo: Perspectiva.

GODARD, Jean-Luc (1985). Jean-Luc Godard par Jean-Luc Godard. Alain Bergala, éd. Paris: Étoile/Cahiers du Cinéma. 
KIVY, Peter (1993). The Fine Art of Repetition. Cambridge: Cambridge University Press.

LOTMAR, Iuri (1978). A Estrutura do Texto Artístico. Lisboa: Estampa.

MACCABE, Colin (1980). Godard: Images, Sounds, Politics. Bloomington: Indiana University Press.

ONG, Walter (1987). Oralidad y Escritura: Tecnologías de la Palavra. México: Fondo de Cultura Económica.

PALLOTTINI, Renata (1998). Dramaturgia de Televisão. São Paulo: Moderna.

PERLOFF, Marjorie (1995). "Introduction". In Postmodern Genres. M. Perloff, ed. Norman: University of Oklahoma Press.

VILCHES, Lorenzo (1984). "Play It Again, Sam”. In Analisi, no. 9. 